\title{
Isolation of the anaerobic thermoacidophilic crenarchaeote Acidilobus saccharovorans sp. nov. and proposal of Acidilobales ord. nov., including Acidilobaceae fam. nov. and Caldisphaeraceae fam. nov.
}

Correspondence

M. I. Prokofeva prokofeva@gmail.com

\author{
M. I. Prokofeva, ${ }^{1}$ N. A. Kostrikina, ${ }^{1}$ T. V. Kolganova, ${ }^{2}$ T. P. Tourova, ${ }^{1}$ \\ A. M. Lysenko, ${ }^{1}$ A. V. Lebedinsky ${ }^{1}$ and E. A. Bonch-Osmolovskaya ${ }^{1}$ \\ ${ }^{1}$ Institute of Microbiology, Russian Academy of Sciences, Prospect 60-letiya Oktyabrya 7/2, \\ 117312 Moscow, Russia \\ ${ }^{2}$ Bioengineering Center, Russian Academy of Sciences, Prospect 60-letiya Oktyabrya 7/1, 117312
Moscow, Russia
}

Obligately anaerobic thermoacidophilic archaea are represented by only a few genera. The only representative of the phylum Euryarchaeota is 'Aciduliprofundum boonei' (Reysenbach et al., 2006), the first thermoacidophilic micro-organism isolated from deep-sea hydrothermal vents. All of the other anaerobic thermoacidophiles belong

The GenBank/EMBL/DDBJ accession number for the $16 \mathrm{~S}$ rRNA gene sequence of strain $345-15^{\top}$ is AY350586.

A table showing the characteristics of strain $345-15^{\top}$ and closely related species is available as supplementary material with the online version of this paper. to the phylum Crenarchaeota and were isolated from terrestrial hot springs and sea-shore hot vents. Obligately respiring, anaerobic, chemolithotrophic thermoacidophiles that grow by means of reduction of elemental sulfur with molecular hydrogen belong to the genus Stygiolobus (Segerer et al., 1991). Organotrophic thermoacidophilic crenarchaeota representing the genera Thermocladium (Itoh et al., 1998), Caldivirga (Itoh et al., 1999) and Vulcanisaeta (Itoh et al., 2002) were described as anaerobes able to tolerate low levels of oxygen. Another group of organotrophic thermoacidophilic archaea includes the genera Acidilobus (Prokofeva et al., 2000) and 
Caldisphaera (Itoh et al., 2003). Whereas the type species of the first genus is an obligate anaerobe, Caldisphaera lagunensis has been reported to be able to grow in the presence of low oxygen concentrations. Initially the genera Acidilobus and Caldisphaera were represented by a single species - Acidilobus aceticus isolated from an acidic hot spring near Moutnovskii Volcano (Kamchatka, Russia) and Caldisphaera lagunensis obtained from an acidic hot spring at Mt Maquiling (Laguna, Philippines). Later, another two species of these genera - 'Acidilobus sulfurireducens' and 'Caldisphaera draconis' - were isolated from acidic hot springs of Yellowstone National Park (Boyd et al., 2007). It was shown that micro-organisms of this group comprise a significant part of microbial communities in sulfur-rich, acidic hot springs $(12.2-32.3 \%$ of the total microbial population for 'Caldisphaera draconis' and 5.3-7.9\% for 'Acidilobus sulfurireducens'). Strains and 16S rRNA clones exhibiting a $93-97 \%$ nucleotide sequence similarity with the type species of the genera Acidilobus or Caldisphaera were obtained from acidic hot springs of different areas of Kamchatka (Prokofeva et al., 2005), Yellowstone National Park (Meyer-Dombard et al., 2005; Korf et al., 2006; Boyd et al., 2007), and Lassen Volcanic National Park in California, USA (Siering et al., 2006), showing the wide distribution of these genera.

Here we present the characterization of a novel thermoacidophilic archaeon belonging to the genus Acidilobus and propose a new order, Acidilobales ord. nov., which includes the families Acidilobaceae fam. nov. and Caldisphaeraceae fam. nov.

\section{Sample collection, enrichment and isolation}

For cultivation, the following basal medium was used

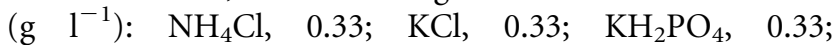
$\mathrm{CaCl}_{2} \cdot 2 \mathrm{H}_{2} \mathrm{O}, 0.33 ; \mathrm{MgCl}_{2} \cdot 6 \mathrm{H}_{2} \mathrm{O}, 0.33$; trace elements (Kevbrin \& Zavarzin, 1992), $10 \mathrm{ml} \mathrm{l}^{-1}$; vitamins (Wolin et al., 1963), $10 \mathrm{ml} \mathrm{l}^{-1}$. Starch or sucrose $\left(2 \mathrm{~g} \mathrm{l}^{-1}\right)$ were added as substrates in the presence of yeast extract $(0.1 \mathrm{~g}$ $\left.1^{-1}\right)$. The medium was prepared anaerobically $(10 \mathrm{~min}$ of boiling and reduction with $600 \mathrm{mg} \mathrm{Na} 2 \mathrm{~S} .9 \mathrm{H}_{2} \mathrm{O} \mathrm{l}^{-1}$ ) and dispensed as $10 \mathrm{ml}$ portions into $15 \mathrm{ml}$ Hungate tubes; $\mathrm{CO}_{2}$ was used as the gas phase. The $\mathrm{pH}$ of the medium, measured at $20{ }^{\circ} \mathrm{C}$ using a pH meter calibrated at $20{ }^{\circ} \mathrm{C}$, was adjusted with $3 \mathrm{M} \mathrm{HCl}$ or $\mathrm{H}_{2} \mathrm{SO}_{4}$. The $\mathrm{pH}$ and cultivation temperature were close to those at the respective sampling sites. Enrichment cultures were obtained at $85{ }^{\circ} \mathrm{C}$ and $\mathrm{pH}$ 3.5-4.0 from samples of Uzon Caldera and Moutnovskii Volcano, Kamchatka and Golovnin Caldera, Kunashir, Kuril Islands. These enrichments have been described previously (Prokofeva et al., 2005). The dominant micro-organisms from these cultures were isolated from the highest positive dilution after two rounds of serial dilutions on medium containing $2 \mathrm{~g}$ maltose $1^{-1}$. Strain $345-15^{\mathrm{T}}$ was isolated from a sample (mixture of water and mud) from a hot acidic pool $\left(T=85^{\circ} \mathrm{C}, \mathrm{pH} 3.5-4.0\right)$ with grey loamy mud $\left(54^{\circ} 30^{\prime} 40^{\prime \prime}\right.$ $\mathrm{N} 160^{\circ} 00^{\prime} 06^{\prime \prime} \mathrm{E}$ ) located on the Orange Thermal Field
(Uzon Caldera, Kamchatka, Russia; see also Perevalova et al., 2008) and was chosen for detailed characterization.

\section{Morphology and growth characteristics}

Cells of strain $345-15^{\mathrm{T}}$ were regular to irregular cocci, 1$2 \mu \mathrm{m}$ in diameter. Motility was not observed using a light microscope (MBI-3 with phase-contrast; LOMO). However, in electron micrographs of whole exponentialphase cells of strain $345-15^{\mathrm{T}}$ stained negatively [with $2 \%$ phosphotungstic acid on Formvar (Serva)-coated copper grids and examined using a JEM-100B (JEOL) electron microscope operated at $60 \mathrm{kV}$ ], they were found to possess flagella (Fig. 1a). To obtain thin sections, cells were fixed with $5 \%$ glutaraldehyde for $2 \mathrm{~h}$ at $4{ }^{\circ} \mathrm{C}$. Additional fixation was also performed with $1 \% \mathrm{OsO}_{4}$ for $4 \mathrm{~h}$ at $4{ }^{\circ} \mathrm{C}$. Cells were embedded in epon-812, and were thin-sectioned on microtone LKB-3R and stained with uranil acetate and lead citrate. The cell envelope was about $30 \mathrm{~nm}$ thick (Fig. 1b).

Growth of isolate $345-15^{\mathrm{T}}$ occurred at a temperature range of $60-90{ }^{\circ} \mathrm{C}$, with optimum growth at $80-85{ }^{\circ} \mathrm{C}$ (no growth occurred at 58 or $94{ }^{\circ} \mathrm{C}$ ) and at a pH range of

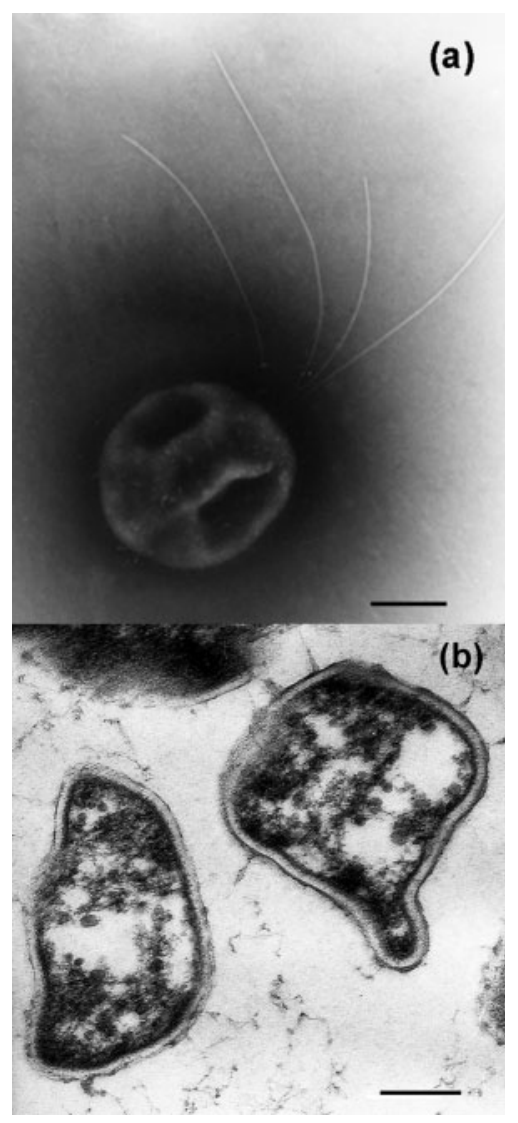

Fig. 1. Electron micrographs of exponential-phase cells of strain $345-15^{\top}$ : (a) whole cells negatively stained with phosphotungstic acid; (b) ultrathin sections stained with uranil-acetate and lead citrate. Bars, $0.5 \mu \mathrm{m}$. 
2.5-5.8, with optimum growth at 3.5-4.0 (no growth occurred at $\mathrm{pH} 2.0$ or 6.0 ).

Potential growth substrates were added to the basal medium at concentrations of $2 \mathrm{~g} \mathrm{l}^{-1}$ (organic acids as their sodium salts). Potential electron acceptors added to the basal medium were elemental sulfur as sulfur powder $\left(10 \mathrm{~g} \mathrm{l}^{-1}\right)$, thiosulfate and nitrate as sodium salts (each as $0.5,1.0$ and $\left.2.5 \mathrm{~g} \mathrm{l}^{-1}\right)$ or $\mathrm{Fe}(\mathrm{III})$ citrate $(20 \mathrm{mM})$. The headspace was filled with $100 \% \mathrm{CO}_{2}$; when molecular hydrogen was tested as the growth substrate, the gas phase used was a mixture of $\mathrm{H}_{2}$ and $\mathrm{CO}_{2}(8: 2, \mathrm{v} / \mathrm{v})$. All growth experiments were carried out in triplicate and (minimum) in three transfers. Growth was measured by direct cell count under a light microscope. Gases, alcohols and volatile fatty acids were determined on GC 'Cristal 5000.1' with FID and TCD (Chromatek, Russia) and lactate - by HPLC on GC 'Stayer' with UV-detector (220 nm, Akvilon, Russia) and column Rezex RDA (Phenomenex, USA), eluent $-0.2 \% \mathrm{H}_{3} \mathrm{PO}_{4} \cdot \mathrm{H}_{2} \mathrm{~S}$ was determined as described previously (Prokofeva et al., 2005).

Strain $345-15^{\mathrm{T}}$ was able to grow on yeast extract, beef extract, soya extract, peptone, starch, glucose, lactose, maltose, sucrose, fructose, galactose, lichenan, laminarin, arbutin, amygdalin and xylan. Yeast extract $\left(0.1 \mathrm{~g} \mathrm{l}^{-1}\right)$ and $\mathrm{CO}_{2}$ in the gas phase were required for growth. No growth occurred with acetate, arabinose, cellulose, formate, glycine, gelatin, gum guar, malate, methanol, pectin, pyruvate, propionate, trehalose, ribose, xylose, fumarate, microcrystalline cellulose, glycine or succinate. The products of glucose and yeast extract fermentation were acetate, ethanol and lactate. Molecular hydrogen was not detected. Growth on sugars and yeast extract was stimulated by elemental sulfur and thiosulfate, which were reduced to hydrogen sulfide, whereas nitrate and $\mathrm{Fe}(\mathrm{III})$ citrate did not stimulate growth of strain $345-15^{\mathrm{T}}$.

Chloramphenicol (100 $\left.\mathrm{mg} \mathrm{l}^{-1}\right)$, penicillin $\left(500 \mathrm{mg} \mathrm{l}^{-1}\right.$ ) and streptomycin $\left(500 \mathrm{mg} \mathrm{l}^{-1}\right)$ were used to test antibiotic resistance. Strain $345-15^{\mathrm{T}}$ appeared to be resistant to all of the antibiotics tested.

\section{DNA composition and phylogenetic analysis}

DNA was isolated by using the procedure of Marmur (1961). The G $+\mathrm{C}$ content of the DNA was determined by using the thermal denaturation method (Owen et al., 1969). The DNA G $+\mathrm{C}$ content was $54.5 \pm 0.5 \mathrm{~mol} \%$ (SEM). 16S rRNA genes were amplified using the Archaea-specific primer 4F (5'-TCCGGTTGATCCTGCCRG-3') and the universal primer 1492R (5'CGGTTACCTTGTTAGGACTT- $3^{\prime}$ ). The PCR products were purified from low-melting agarose using a Wizard PCR-Prep kit (Promega) according to the manufacturer's instructions. Sequencing was performed using a Big Dye Terminator v.3.1 sequencing reaction kit on an ABI 3730 DNA automatic sequencer (Applied Biosystems). Preliminary phylogenetic analysis of the newly determined sequences was done with the NCBI BLAST server (http://
www.ncbi.nlm.nih.gov/BLAST/). The nucleotide sequences were aligned using MAFFT v. 6 (Katoh et al., 2002) with sequences retrieved from GenBank. Positions exhibiting more than $50 \%$ variability were discarded using a specially written program. Phylogenetic trees were reconstructed using TREECONW (Van de Peer \& De Wachter, 1994) with the neighbour-joining method after calculation of the matrix of evolutionary distances with the Jukes and Cantor correction (Jukes \& Cantor, 1969). 16S rRNA gene analysis showed that the new isolates belonged to the Crenarchaeota phylum of the domain Archaea and were closely related to Acidilobus aceticus. The level of 16S rRNA gene similarity between strain $345-15^{\mathrm{T}}$ and Acidilobus aceticus $1904^{\mathrm{T}}$ was $98.1 \%$ [when distinctions due to Ns (nucleotides determined ambiguously) were neglected]. The phylogenetic position of strain $345-15^{\mathrm{T}}$ is shown in Fig. 2. DNA-DNA hybridization between strain $345-15^{\mathrm{T}}$ and Acidilobus aceticus $1904^{\mathrm{T}}$ was performed by using the method of De Ley et al. (1970) and showed a level of $61 \%$ DNA-DNA hybridization.

\section{Comparison with related species}

Strain $345-15^{\mathrm{T}}$ was found to be close to Acidilobus aceticus both phylogenetically and phenotypically: it is a hyperthermophilic acidophilic coccus that grows anaerobically on organic substrates; its growth is stimulated by sulfur. However, it differs from Acidilobus aceticus by having a much wider spectrum of substrates utilized: in addition to yeast extract and starch, which are the only growth substrates used by Acidilobus aceticus, strain $345-15^{\mathrm{T}}$ can also utilize mono- and disaccharides. Based on these phenotypic differences, as well as the level of 16S rRNA gene sequence similarity and the results of DNA-DNA hybridization with Acidilobus aceticus $1904^{\mathrm{T}}$, we propose that strain $345-15^{\mathrm{T}}$ should be assigned as representing a novel species of the genus Acidilobus - Acidilobus saccharovorans sp. nov. Phylogenetically, strain $345-15^{\mathrm{T}}$ is most close to 'Caldococcus noboribetus' (Aoshima et al., 1996): the level of 16S rRNA gene similarity between strain $345-15^{\mathrm{T}}$ and 'Caldococcus noboribetus' was $99 \%$. The two organisms have certain phenotypic features in common (see Supplementary Table S1, available in IJSEM Online). However, 'Caldococcus noboribetus' still lacks a detailed physiological description. Another Acidilobus species, 'Acidilobus sulfurireducens', was described recently by Boyd et al. (2007), but the name has not been validly published. Strain $345-15^{\mathrm{T}}$ differed from 'Acidilobus sulfurireducens' in the list of substrates used and in the optimum $\mathrm{pH}$ (Supplementary Table S1). The level of 16S rRNA gene similarity between strain $345-15^{\mathrm{T}}$ and 'Acidilobus sulfurireducens' was $96.6 \%$.

\section{GDGT composition}

The isoprenoid glycerol dialkyl glycerol tetraether (GDGT) composition of strain $345-15^{\mathrm{T}}$ was determined by Pearson et al. (2008) and included GDGT-3 (3 cyclopentane rings, 


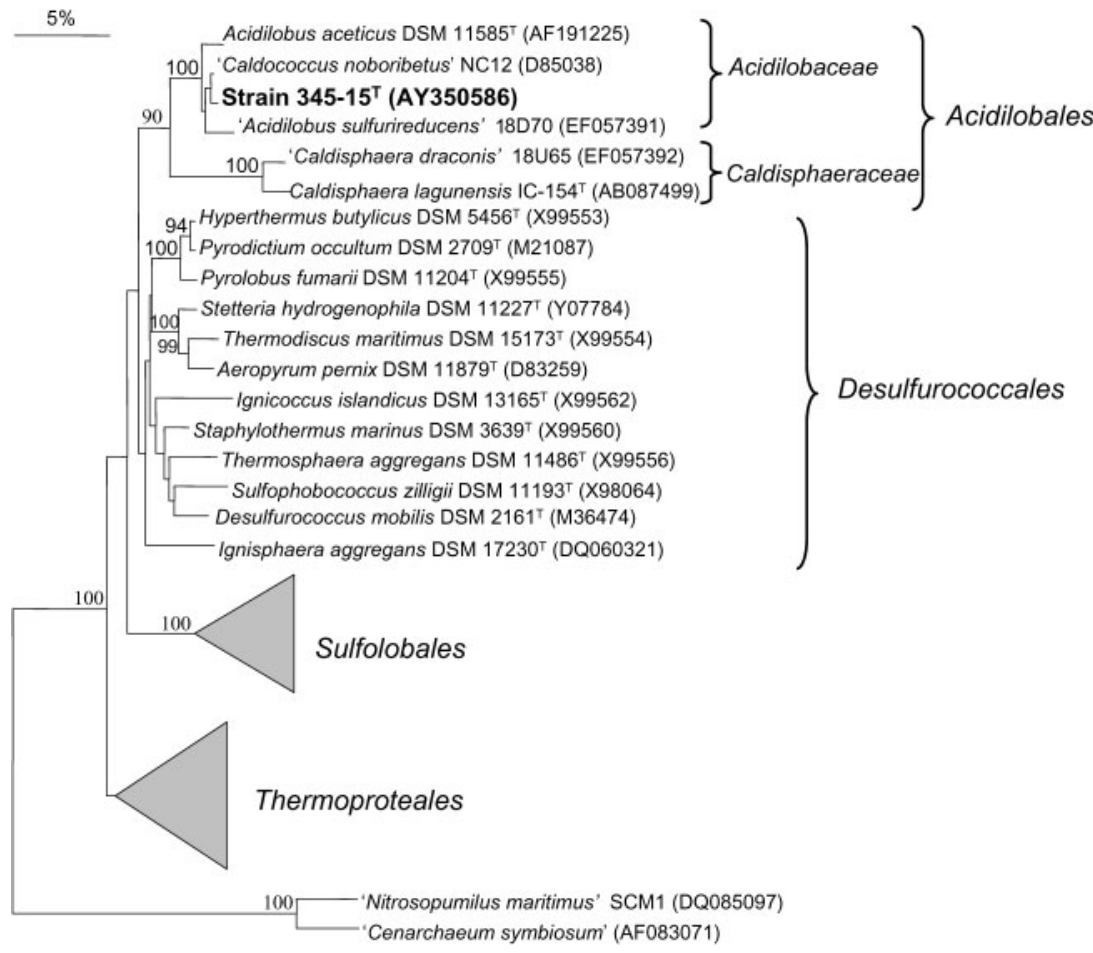

Fig. 2. Phylogenetic dendrogram showing the position of strain $345-15^{\top}$ within the phylum Crenarchaeota. The dendrogram was constructed proceeding from 16S rRNA gene sequences of the type strains of type species of all recognized crenarchaeotal genera, as well as some additional sequences. Numbers at branch points specify the reliability of the branching order determined for 1000 resamplings; only bootstrap values of $90 \%$ and higher are shown. The triangles represent the Sulfolobales representatives Acidianus infernus DSM $3191^{\top}$ (D85505), Metallosphaera sedula DSM 5348 ${ }^{\top}$ (X90481), Stygiolobus azoricus DSM $6296^{\top}$ (D85520), Sulfolobus acidocaldarius DSM 639 ${ }^{\top}$ (D14876) and Sulfurisphaera ohwakuensis DSM $12421^{\top}$ (D85507), and the Thermoproteales representatives Thermofilum pendens DSM $2475^{\top}$ (X14835), Caldivirga maquilingensis DSM $13496{ }^{\top}$ (AB013926), Pyrobaculum islandicum DSM $4184^{\top} \quad$ (L07511), Thermocladium modestius JCM 10088 ${ }^{\top} \quad$ (AB005296), Thermoproteus tenax DSM 2078' (M35966), and Vulcanisaeta distributa DSM $14429^{\top}$ (AB063630). $m / z$ 1296), GDGT-4 and GDGT-4' (4 cyclopentane rings, $m / z$ 1294), isocrenarchaeol GDGT-5' (4 cyclopentane +1 cyclohexane rings, $m / z$ 1292), as well as GDGT-6 and GDGT-6' (six rings, $m / z$ 1290), representing $1,14,2,27,54$ and $2 \%$ of the total GDGTs in the lipid fraction of strain $345-15^{\mathrm{T}}$. In the same work, the GDGT composition of the type strain of Acidilobus aceticus was shown to include acyclic caldarchaeol GDGT-0 $(\mathrm{m} / z$ 1302), GDGT-4 and GDGT-5', representing 20, 34 and $46 \%$ of the total GDGTs. The GDGT composition of 'Acidilobus sulfurireducens' includes GDGT-4, GDGT-5', GDGT-6 and GDGT-6', representing 4, 36, 55 and $5 \%$ of the total GDGTs (Boyd et al., 2007).

\section{Conclusion and proposal of new taxa}

In the latest edition of Bergey's Manual (Garrity et al., 2005), the genus Acidilobus was included in the order Desulfurococcales. At the same time, it was proposed to establish the order Caldisphaerales to include a single genus, Caldisphaera (Itoh et al., 2003), which at present contains two species, Caldisphaera lagunensis and 'Caldisphaera draconis' (Boyd et al., 2007). The genera Caldisphaera and Acidilobus are distantly but specifically related, as shown by their clustering in the 16S rRNA genebased phylogenetic trees with a high level of bootstrap support (Fig. 2), and the presence of common nucleotide signatures in their 16S rRNA genes, distinguishing them from other representatives of the Crenarchaeota (Table 1). Organisms of this group exhibit common phenotypic properties, such as a coccoid cell shape and acidophily (optimum pH 3.0-4.0); they are obligate anaerobes, extremely thermophilic (Caldisphaera spp.) or hyperthermophilic (Acidilobus spp., 'Caldococcus noboribetus') and organotrophic micro-organisms, capable of using elemental sulfur as electron acceptor. This group also includes poorly characterized strains and environmental rRNA gene clones. Strains and clones exhibiting 93-97\% nucleotide sequence similarity with Acidilobus aceticus or with Caldisphaera lagunensis were obtained from various acidic hot springs of different areas (Prokofeva et al., 2005; Meyer-Dombard et al., 2005; Korf et al., 2006; Siering et al., 2006). These strains and clones differ markedly in the DNA $\mathrm{G}+\mathrm{C}$ content (66.9-69.1 mol\% for Acidilobus relatives and 61.2-63.9 mol\% for related Caldisphaera species), which is known to be positively correlated with the temperature optimum of growth (Galtier \& Lobry, 1997; Lebedinsky et al., 2007).

Taking into account the separate position of the AcidilobusCaldisphaera group in the 16S rRNA gene-based phylogenetic tree, the presence in the 16S rRNA gene of common specific signatures, and common phenotypic properties distinguishing the representatives of this group from Desulfurococcales and other Crenarchaeota, as well as their wide distribution in natural thermal ecosystems, we propose a new order, Acidilobales ord. nov., to accommodate this group. The evolutionary divergence of this group may be related to adaptation to anaerobic environments in terrestrial hot springs with low $\mathrm{pH}$ values. It should be noted that, in Archaea, acidophily usually correlates with 
Table 1. 16S rRNA sequence signatures that distinguish Acidilobus and Caldisphaera from other Crenarchaeota and from each other

Signatures were deduced from alignments retrieved from the GreenGenes database updated on June 162008 (623 crenarchaeotal sequences). A particular letter signifies no less than $97 \%$ occurrence of the corresponding nucleotide.

\begin{tabular}{|lcccc|}
\hline Sequence position & \multicolumn{3}{c|}{ Corresponding nucleotides } \\
\cline { 2 - 5 } & Acidilobus & Caldisphaera & Desulfurococcales, Thermoproteales, Sulfolobales & All Crenarchaeota \\
\hline 62 & $\mathrm{U}$ & $\mathrm{C}$ & $\mathrm{U}$ & $\mathrm{U}$ \\
$321: 332$ & $\mathrm{C}: \mathrm{G}$ & $\mathrm{C}: \mathrm{G}$ & $\mathrm{A}: \mathrm{G}$ & $\mathrm{A}: \mathrm{G}$ \\
678 & $\mathrm{C}$ & $\mathrm{U}$ & $\mathrm{U}$ & $\mathrm{U}$ \\
1056 & $\mathrm{U}$ & $\mathrm{C}$ & $\mathrm{A}: \mathrm{U}$ & $\mathrm{U}$ \\
$1310: 1327$ & $\mathrm{G}: \mathrm{C}$ & $\mathrm{A}: \mathrm{U}$ & $\mathrm{G}$ & $\mathrm{A}, \mathrm{C}, \mathrm{G}$ \\
1335 & $\mathrm{C}$ & $\mathrm{C}$ & $\mathrm{C}$ & $\mathrm{C}$ \\
1393 & $\mathrm{U}$ & $\mathrm{U}$ & & $\mathrm{A}$ \\
\hline
\end{tabular}

${ }^{\star}$ Escherichia coli numbering.

phylogenetic position: among the Crenarchaeota, apart from the members of the group under consideration, all members of the order Sulfolobales (aerobes) and certain representatives of the order Thermoproteales (anaerobes) are acidophilic. In Euryarchaeota, all members of the order Thermoplasmales and the only cultured representative of the deep DHVE2 phylogenetic lineage - 'Aciduliprofundum boonei are acidophilic.

Based on the distinct positions of Acidilobus and Caldisphaera in the phylogenetic tree, the existence of specific 16S rRNA signatures that distinguish them (Table 1), as well as different ranges of growth temperatures, we propose two families within the order Acidilobales: family Acidilobaceae fam. nov., represented by the hyperthermophilic genus Acidilobus and by the phylogenetically close species 'Caldococcus noboribetus' and environmental clones; and the family Caldisphaeraceae fam. nov., represented by the extremely thermophilic genus Caldisphaera, and by related environmental clones.

\section{Description of Acidilobales ord. nov.}

Acidilobales (A.ci.di.lo.ba'les. N.L. masc. n. Acidilobus the type genus of the order, suff. -ales ending denoting an order; N.L. fem. pl. n. Acidilobales the order of Acidilobus).

Cells are regular to irregular cocci. Anaerobic. Extremely thermophilic or hyperthermophilic. Acidophilic. Organotrophic, able to use carbohydrates and peptides in the absence of electron acceptors or in the presence of sulfur. Elemental sulfur stimulates growth. Habitats are terrestrial acidic hot springs. The type genus is Acidilobus Prokofeva et al. 2000.

Includes Acidilobaceae fam. nov. and Caldisphaeraceae fam. nov.

\section{Description of Acidilobaceae fam. nov.}

Acidilobaceae (A.ci.di.lo.ba.ce'a.e. N.L. masc. n. Acidilobus the type genus of the family, suff. -aceae ending denoting a family; N.L. fem. pl. n. Acidilobaceae the family of Acidilobus).

Cells are regular to irregular cocci, $1-2 \mu \mathrm{m}$ in diameter. Strictly anaerobic. Hyperthermophilic. Acidophilic. Organotrophic, able to use carbohydrates and peptides. Hydrogen is not formed even in the absence of electron acceptors. Growth is stimulated by the presence of elemental sulfur. Resistant to chloramphenicol, penicillin and streptomycin. Habitats are acidic terrestrial hot springs. The type genus is Acidilobus Prokofeva et al. 2000.

\section{Description of Caldisphaeraceae fam. nov.}

Caldisphaeraceae (Cal.di.spha.e.ra.ce'a.e. N.L. fem. n. Caldisphaera the type genus of the family, suff. -aceae ending denoting a family; N.L. fem. pl. n. Caldisphaeraceae the family of Caldisphaera).

Cells are regular cocci, $0.8-1.1 \mu \mathrm{m}$ in diameter. Anaerobic. Extremely thermophilic. Acidophilic. Organotrophic, able to use carbohydrates and peptides in the absence of electron acceptors. Growth is stimulated by the presence of sulfur. Resistant to chloramphenicol, kanamycin, oleandomycin, streptomycin and vancomycin. Habitats are terrestrial acidic hot springs. The type genus is Caldisphaera Itoh et al. 2003.

\section{Emended description of the genus Acidilobus}

Cell envelope consists of an S-layer covering the cytoplasmic membrane. Hyperthermophiles with a temperature range of $60-92{ }^{\circ} \mathrm{C}$ and an optimum of $80-85^{\circ} \mathrm{C}$. Acidophiles with a $\mathrm{pH}$ range of 2.0 to 6.0 (optimum at $\mathrm{pH}$ 3.5-4.0). Obligate anaerobes. Organotrophs. Peptides, polysaccharides, and monosaccharides can serve as energy and carbon sources in the absence of electron acceptors. Acetate, ethanol and lactate are the fermentation products. Hydrogen is not produced. Elemental sulfur stimulates growth and is reduced to hydrogen sulfide. Resistant to 
chloramphenicol, penicillin and streptomycin. The G+C content of the total DNA is around 53-60 mol\%. The type species is Acidilobus aceticus. Habitats: terrestrial acidic hot springs.

\section{Description of Acidilobus saccharovorans sp. nov.}

Acidilobus saccharovorans (sac.cha.ro.vo' rans. Gr. neut. n. saccharon sugar; L. part. adj. vorans devouring; N.L. masc. adj. saccharovorans sugar-devouring).

Exhibits the following properties in addition to those given in the genus description. Cells are regular to irregular cocci, $1-2 \mu \mathrm{m}$ in diameter. Growth occurs at $60-90{ }^{\circ} \mathrm{C}$ (optimum, $80-85{ }^{\circ} \mathrm{C}$ ) and at $\mathrm{pH}$ 2.5-5.8 (optimum, 3.5-4.0). Strictly anaerobic. Heterotrophic. Growth occurs on yeast extract, peptone, starch, glucose, lactose, maltose, sucrose, fructose, galactose, lichenan, laminarin, arbutin, amygdalin and xylan. Elemental sulfur and thiosulfate stimulate growth on yeast extract but are not obligately required. Growth product from sugars are acetate, ethanol, lactate and, in the presence of $\mathrm{S}^{\mathrm{o}}, \mathrm{H}_{2} \mathrm{~S}$. The DNA $\mathrm{G}+\mathrm{C}$ content of the type strain is $54.5 \mathrm{~mol} \%$.

The type strain, $345-15^{\mathrm{T}}\left(=\mathrm{DSM} 16705^{\mathrm{T}}=\mathrm{VKM} \mathrm{B}-2471^{\mathrm{T}}\right)$, was isolated from a hot acidic pool in the Orange Thermal Field of Uzon Caldera, Kamchatka, Russia.

\section{Acknowledgements}

We acknowledge the support of the Programs of the Russian Academy of Sciences 'Molecular and Cell Biology' and 'Origin and Evolution of the Biosphere', of the Russian Foundation of Basic Research (project 06-04-49045) Federal Agency for Science and Innovations of Russia (contract 02.512.11.2201), as well as of the NSF-funded research grant 'Microbial Observatory Kamchatka, an International Interdisciplinary Research Project' (NCF MCB02238407).

\section{References}

Aoshima, M., Nishibe, Y., Hasegawa, M., Yamagishi, A. \& Oshima, T. (1996). Cloning and sequencing of a gene encoding $16 \mathrm{~S}$ ribosomal RNA from a novel hyperthermophilic archaebacterium NC12. Gene 180, 183-187.

Boyd, E. S., Jackson, R. A., Encarnasion, G., Zahn, J. A., Beard, T., Leavitt, W. D., Pi, Y., Zhang, C. L., Pearson, A. \& Geesey, G. G. (2007). Isolation, characterization, and ecology of sulfur-respiring crenarchaea inhabiting acid-sulfate-chloride-containing geothermal spring in Yellowstone National Park. Appl Environ Microbiol 73, 6669-6677.

De Ley, J., Cattoir, H. \& Reynaerts, A. (1970). The quantitative measurement of DNA hybridization from renaturation rates. Eur $J$ Biochem 12, 133-142.

Galtier, N. \& Lobry, J. R. (1997). Relationships between genomic G + C content, RNA secondary structures, and optimal growth temperature in prokaryotes. J Mol Evol 44, 632-636.
Garrity, G. M., Bell, J. A. \& Lilburn, T. (2005). The revised road map to the Manual. In Bergey's Manual of Systematic Bacteriology, 2nd edn, vol. 2, part A, pp. 159-187. Edited by D. J. Brenner, N. R. Krieg, J. T. Staley \& G. M. Garrity. New York: Springer.

Itoh, T., Suzuki, K. \& Nakase, T. (1998). Thermocladium modestius gen. nov., sp. nov., a new genus of rod-shaped, extremely thermophilic crenarchaeote. Int J Syst Bacteriol 48, 879-887.

Itoh, T., Suzuki, K., Sanchez, P. C. \& Nakase, T. (1999). Caldivirga maquilingensis gen. nov., sp. nov., a new genus of rod-shaped crenarchaeote isolated from a hot spring in the Philippines. Int J Syst Bacteriol 49, 1157-1163.

Itoh, T., Suzuki, K. \& Nakase, T. (2002). Vulcanisaeta distributa gen. nov., sp. nov., and Vulcanisaeta souniana sp. nov., novel hyperthermophilic, rod-shaped crenarchaeotes isolated from hot springs in Japan. Int J Syst Evol Microbiol 52, 1097-1104.

Itoh, T., Suzuki, K., Sanchez, P. C. \& Nakase, T. (2003). Caldisphaera lagunensis gen. nov., sp. nov., a novel thermoacidophilic crenarchaeote isolated from a hot spring at Mt Maquiling, Philippines. Int J Syst Evol Microbiol 53, 1149-1154.

Jukes, T. H. \& Cantor, C. R. (1969). Evolution of protein molecules. In Mammalian Protein Metabolism, vol. 3, pp. 21-132. Edited by H. N. Munro. New York: Academic Press.

Katoh, K., Misawa, K., Kuma, K. \& Miyata, T. (2002). MAFFT: a novel method for rapid multiple sequence alignment based on fast Fourier transform. Nucleic Acids Res 30, 3059-3066.

Kevbrin, V. V. \& Zavarzin, G. A. (1992). The influence of sulfur compounds on the growth of halophilic homoacetic bacterium Acetohalobium arabaticum. Microbiology 61, 563-571 (English translation of Mikrobiologiia).

Korf, S. E., Macur, R. E., Nagy, A. M., Tayler, W. P., Kozubal, M. A., Ackerman, G., Masur, D. \& Inskeep, W. P. (2006). Geochemical controls on microbial population distribution at Rainbow and Joseph's Coat hot springs in Yellowstone National Park (unpublished, reference in GenBank documents).

Lebedinsky, A. V., Chernyh, N. A. \& Bonch-Osmolovskaya, E. A. (2007). Phylogenetic systematics of microorganisms inhabiting thermal environments. Biochemistry 72, 1299-1312.

Marmur, J. (1961). A procedure for the isolation of deoxyribonucleic acid from microorganisms. J Mol Biol 3, 208-218.

Meyer-Dombard, D. R., Shock, E. L. \& Amend, J. P. (2005). Archaeal and bacterial communities in geochemically diverse hot springs of Yellowstone National Park, USA. Geobiology 3, 211-227.

Owen, R. J., Hill, L. R. \& Lapage, S. P. (1969). Determination of DNA base composition from melting profiles in dilute buffer. Biopolymers 7, 503-516.

Pearson, A., Pi, Y., Zhao, W., Li, W. J., Li, Y., Inskeep, W., Perevalova, A., Romanek, C., Li, S. \& Zhang, C. L. (2008). Factors controlling the distribution of archaeal tetraethers in terrestrial hot springs. Appl Environ Microbiol 74, 3523-3532.

Perevalova, A. A., Kolganova, T. V., Birkeland, N.-K., Schleper, C., Bonch-Osmolovskaya, E. A. \& Lebedinsky, A. V. (2008). Distribution of Crenarchaeote representatives in terrestrial hot springs of Russia and Iceland. Appl Environ Microbiol 74, 7620-7628.

Prokofeva, M. I., Miroshnichenko, M. L., Kostrikina, N. A., Chernyh, N. A., Kuznetsov, B. B., Tourova, T. P. \& Bonch-Osmolovskaya, E. A. (2000). Acidilobus aceticus gen. nov., sp. nov., a novel anaerobic thermoacidophilic archaeon from continental hot vents in Kamchatka. Int J Syst Evol Microbiol 50, 2001-2008.

Prokofeva, M. I., Kublanov, I. V., Nercessian, O., Tourova, T. P., Kolganova, T. V., Lebedinsky, A. V., Bonch-Osmolovskaya, E. A., Spring, S. \& Jeanthon, C. (2005). Cultivated anaerobic acidophilic/ 
acidotolerant thermophiles from terrestrial and deep-sea hydrothermal habitats. Extremophiles 9, 437-448.

Reysenbach, A.-L., Liu, Y., Banta, A. B., Beveridge, T. J., Kirshtein, J. D., Schouten, S., Tivey, M. K., Von Damm, K. L. \& Voytek, M. A. (2006). A ubiquitous thermoacidophilic archaeon from deep-sea hydrothermal vents. Nature 442, 444-447.

Segerer, A. H., Trincone, A., Gahrtz, M. \& Stetter, K. O. (1991). Stygiolobus azoricus gen., sp. nov. represents a novel genus of anaerobic, extremely thermoacidophilic archaebacteria of the order Sulfolobales. Int J Syst Bacteriol 41, 495-501.
Siering, P. L., Clarke, J. M. \& Wilson, M. S. (2006). Geochemical and biological diversity in acidic, hot springs in Lassen Volcanic National Park. Geomicrobiol J 23, 129-141.

Van de Peer, Y. \& De Wachter, R. (1994). TREECON for Windows: a software package for the construction and drawing of evolutionary trees for the Microsoft Windows environment. Comput Appl Biol Sci 10, 569-570.

Wolin, E. A., Wolin, M. J. \& Wolfe, R. S. (1963). Formation of methane by bacterial extracts. J Biol Chem 238, 2882-2888. 